\title{
A seemingly on-going sound change in Takuu language of Papua New Guinea: historical and theoretical implications*
}

\begin{abstract}
The Takuu language of Papua New Guinea shows both the lateral [1] and the flap rhotic [r] as regular reflexes of Proto-Nuclear-Polynesian *l. Older speakers tend to pronounce it closer to [r] and younger speakers closer to [1]. This situation is likely to be described as a sound change in progress $(r \rightarrow l)$. However, it is possible to show that distribution of [1] and $[\mathrm{r}]$ is predictable, depending on strictly defined phonological environments and the age of the speaker. Thus, a seemingly on-going sound change turns out to be a series of seven different related sound changes which trigger each other. The closely related languages Nukeria and Nukumanu whose speakers maintain close contact with Takuu show only a part of the Takuu distributional patterns for liquids; in these cases we probably deal with shared sound changes that have recently originated in one of the languages. Intricate distributions involving laterals and rhotics on one hand and fricatives on the other are characteristic of Polynesian Outliers. The author suggests that distributions of this kind are responsible for irregular reflexes of Proto-Polynesian liquids and fricatives in modern Polynesian languages.
\end{abstract}

Keywords: sound change in progress, irregular sound changes, shared phonological innovations, theory of sound change, geminate consonants, liquid consonants, Polynesian languages, Polynesian Outliers, Takuu language of Papua New Guinea.

Aller Lautwandel, soweit er mechanisch vor sich geht, vollzieht sich nach ausnahmslosen Gesetzen, d.h. die Richtung der Lautbewegung ist bei allen Angehörigen einer Sprachgenossenschaft, außer dem Fall, daß Dialektspaltung eintritt, stets dieselbe, und alle Wörter, in denen der der Lautbewegung unterworfene Laut unter gleichen Verhältnissen erscheint, werden ohne Ausnahme von der Veränderung ergriffen.

Hermann Osthoff und Karl Brugmann (1878), Morphologische Untersuchungen auf dem Gebiete der indogermanischen Sprachen. Band I. Hildesheim. S. XIII.

Takuu is a Polynesian Outlier spoken in the Autonomous Region of Bougainville, Papua New Guinea. Despite the turbulent history of the island, 12 Takuu survivors at the beginning of the

* Friends, colleagues and accidental strangers have all contributed to the uneasy birth of this study; I cannot mention all of them here. First of all, I would like to thank the people of Papua New Guinea who were always ready to help and make me feel at home on my way - Aruka Kareva, Brendon Wells, Edmond Teppuri, Rumano Mahara and Tom Puaria. This work would not be possible without the help of Claire Moyse, Maria Gaida, Nico Daams, Richard Feinberg, Ross Clark, Vladimir Belikov and many others. I am very grateful to Evgenia Korovina and William Wilson for their comments on a preliminary version of the paper. The field research has been supported by the Foundation for Fundamental Linguistic Research (2012) and by the Program of strategic development of the Russian State University for the Humanities (2013).

Journal of Language Relationship • Вопросы языкового родства • 12 (2014) • Pp. 1-20 • ( ) Davletshin A., 2014 


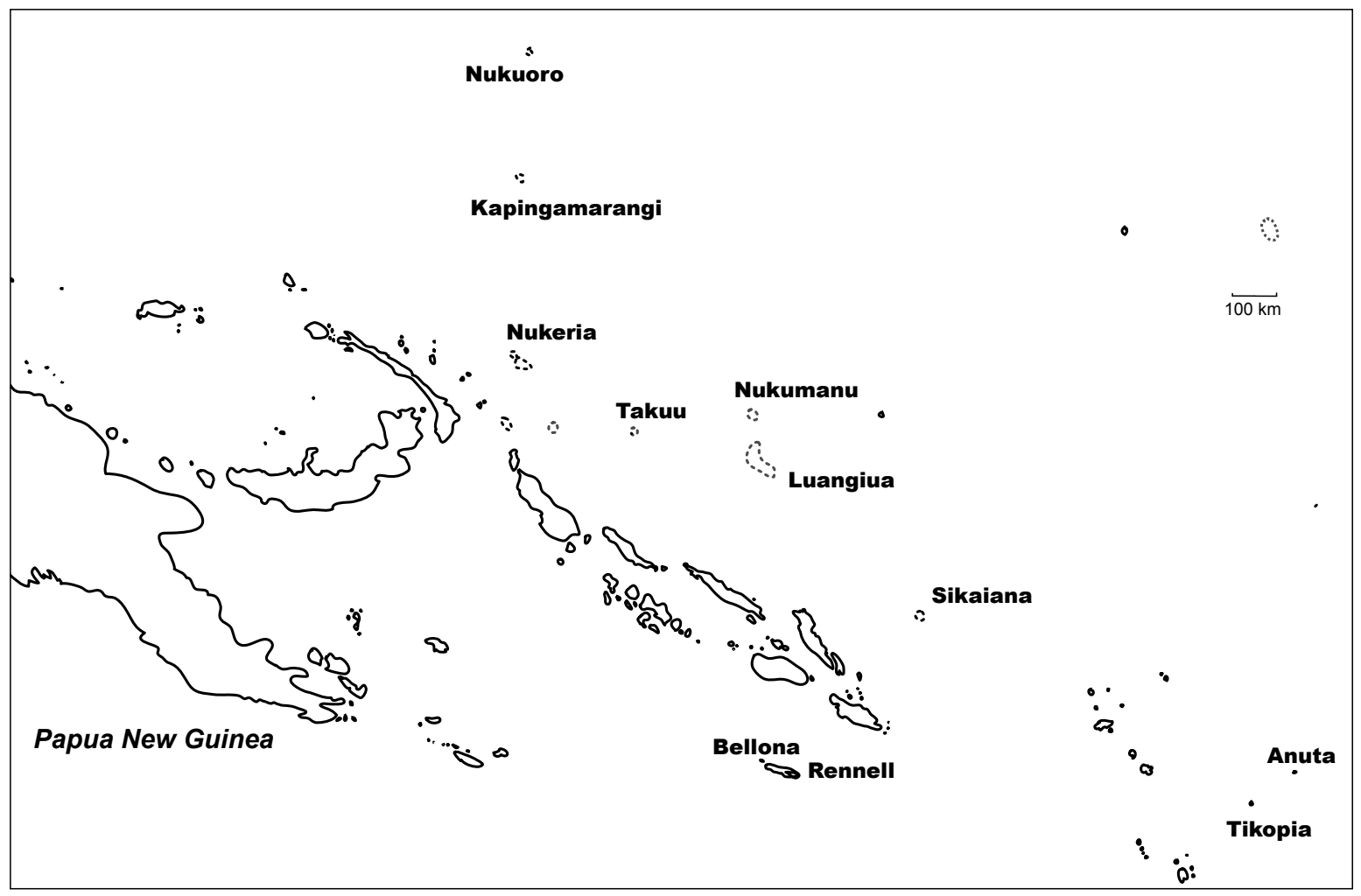

Figure 1. Map of Near Oceania. Captions indicate locations of the Polynesian Outlier languages mentioned in the text. Drawing by the author.

$20^{\text {th }}$ century had managed to keep their indigenous language and traditional practices alive. In the historical, cultural, and geographical aspects Takuu is particularly close to Nukeria and Nukumanu Polynesian Outliers of Papua New Guinea (Map 1) ${ }^{1}$. Since the Takuu chose to ban Christian churches and missionaries in the 1960s, it is probably the last community where traditional Polynesian religion is still openly practised. Nowadays, the number of speakers is approximately 2000 and Takuu's social community is spread widely throughout Papua New Guinea; some 500 of them live on the atoll itself.

Since 1995, Richard Moyle has published a number of papers and three monographs on Takuu culture and language, based on his field research. His recent book became the first description of the language which includes a dictionary and a brief grammatical sketch (Moyle 2011). In Takuu, both [1] and [r] represent reflexes of Proto-Nuclear-Polynesian * $l$. Here are some examples from my first Takuu wordlist that I collected on Buka (for Proto-Polynesian reconstructions see Greenhill and Clark 2011). ${ }^{2}$

$\begin{array}{lll}\text { ['hua'rooroa] } & \text { 'long (of rope)' } & \leftarrow \text { pNP *loa } \\ \text { [i'loa] } & \text { 'to know' } & \leftarrow \text { pNP * } 2 \text { iloa }\end{array}$

${ }^{1}$ I use the term "Nukeria", since my consultants insist that it is the correct name of their language. According to them, "Nukuria" is a word from the "trade language", which is what they call a language variety that Takuu, Nukeria and Nukumanu speakers use when they gather together.

2 I make use of the following abrreviations: caus. = 'causative', dem. = 'demonstrative', dl. = 'dual', freq. = 'frequentative', imper. = 'imperative', indep. = 'independent (of pronoun)', pass. = 'passive', pl. = 'plural', pron. = 'pronoun', sg. = ‘singular', syn. = ‘synonym’ (see Moyle 2011: ix-x). 


\begin{tabular}{|c|c|c|}
\hline ['kere'kere] & 'earth’ & $\leftarrow$ pNP ${ }^{*}$ kele \\
\hline ['kiri] & 'bark (of tree)' & $\leftarrow \mathrm{pNP}^{*}$ kili \\
\hline ['laa] & 'the Sun' & $\leftarrow \mathrm{pNP}^{*} \mathrm{la} 3 \mathrm{a}$ \\
\hline ['laakau] & 'tree' & $\leftarrow$ pNP ${ }^{*}$ larakau \\
\hline [le'llere] & 'flying (of birds)' & $\leftarrow$ pNP ${ }^{*}$ lele \\
\hline ['lua] & 'two' & $\leftarrow$ pNP ${ }^{*}$ lua \\
\hline [ma'rama] & 'the Moon' & $\leftarrow$ pNP *malama \\
\hline [piso'uru] & 'head' & $\leftarrow \mathrm{pNP}^{*} \mathrm{qulu}$ \\
\hline ['raa] & 'that' & $\leftarrow$ pNP *laa \\
\hline ['rima] & 'hand' & $\leftarrow \mathrm{pNP}{ }^{*} \operatorname{lima}$ \\
\hline ['rua] & 'hole' & $\leftarrow \mathrm{pNP}^{*}$ lua \\
\hline ['tee'laa] & 'that (dem. indep.)' & $\leftarrow$ pNP ${ }^{*}$ teelaa \\
\hline
\end{tabular}

Richard Moyle describes this situation as a change in progress. However, he writes that not all speakers agree that the two sounds are in free variation, with some insisting that only [1] is acceptable in some words, e.g. ['laatou], ['lono], ['luu], ['moli]. There are instances where the shift from [1] to [r] has affected only part of the word, so that some may contain both $l$ and $r$, e.g. ['laro] and [la'rana]. Some use [r], but others believe that use of [1] in certain words is the 'correct' pronunciation of those words (Moyle 2011: 8-9). While working with Takuu speakers in 2013, I was puzzled by the same questions. Subsequently, this paper offers the results of my attempts to solve the Takuu 'linguistic challenge'.

First, I will make a brief sketch of Takuu phonology. Then I will describe the system of Takuu geminate consonants, a necessary pre-requisite for discussion of Takuu liquids. After that I will try to define and chronologically order the distributional patterns for Takuu liquids. Later, I will look for similar phenomena in genetically related languages, and finally, I will discuss the implications of my findings for Polynesian linguistics and theory of sound change in general.

\section{Takuu phonology}

Takuu has relatively few distinctive phonological units in its phonemic inventory. However, both consonant and vowel geminates are attested in the language.

Table 1. Inventory of distinctive segments.

\begin{tabular}{c|c|c}
\hline $\mathrm{p}$ & $\mathrm{t}$ & $\mathrm{k}$ \\
\hline $\mathrm{m}$ & $\mathrm{n}$ & \\
\hline $\mathrm{f} \sim \mathrm{h}$ & $\mathrm{s}$ & \\
\hline $\mathrm{v}$ & $\mathrm{l}, \mathrm{r}$ & \\
\hline
\end{tabular}

\begin{tabular}{c|c|c}
\hline $\mathrm{pp}$ & $\mathrm{tt}$ & $\mathrm{kk}$ \\
\hline $\mathrm{mm}$ & $\mathrm{nn}$ & \\
\hline $\mathrm{ff}$ & $\mathrm{ss}$ & \\
\hline $\mathrm{vv}$ & $\mathrm{ll}$ & \\
\hline
\end{tabular}

\begin{tabular}{c|c|c}
\hline $\mathrm{i}$ & & $\mathrm{u}$ \\
\hline $\mathrm{e}$ & & $\mathrm{o}$ \\
\hline & $\mathrm{a}$ & \\
\hline
\end{tabular}

\begin{tabular}{c|c|c}
\hline ii & & uu \\
\hline ee & & oo \\
\hline & aa & \\
\hline
\end{tabular}

Like most other Polynesian languages, Takuu shows some allophonic variation conditioned by phonological environments. The velar $/ k /$ is sometimes realised as dorso-uvular [q] 
in the context of the non-front vowels $/ a /, / o /$ and $/ u /$. In isolation the final monomoraic middle vowels $/ e /$ and $/ o /$ are raised and pronounced close to the corresponding high vowels [i] and [u], e. g. ['koi] /koe/ '2nd person, sg.', ['namu] /namo/ 'lagoon inside a reef', etc.

According to Richard Moyle (2011: 8), there are widely differing opinions on whether [f] and $[\mathrm{h}$ ] could be seen as free variants in Takuu, e.g. [faa'faa $\sim$ haa'haa] 'to touch with hand', ['fare 'hare] 'house', [afi'afi ahi'ahi] 'evening'. For a small number of words, individual speakers insist that only [f] is acceptable, e.g. [fe'tuu] 'star'. However, there appears to be no agreement as to what those words are. According to my consultant, [h] is the only acceptable pronunciation of the non-geminate consonant and [ff] is the only acceptable pronunciation of its geminate counterpart (my principal Takuu consultant is male and about 50 years old).

Takuu resembles most other Polynesian languages in allowing only open syllables and prohibiting consonant clusters, although vowel sequences appear to be unrestricted. The only permitted consonant cluster [nt] is found in the intervocalic pre-stressed position, e.g. [kan'tua $\sim$ kana'tua] 'back (of the body)', [pon'tau pono'tau] 'large box-like logs drifted on to the island long time ago; as soon as they touched land, they opened up and warriors (masaurani spirits) got off and attacked the islanders (mythical)', [man'tee] 'Monday' and [san'tee] 'Sunday'.

Primary stress falls on the penultimate vocalic mora; secondary stress is placed on every second mora to the left of the stressed mora. This implies that long vowels are sequences of two identical short vowels, so that long vowels do not constitute independent phonological segments, cf. ['mano] 'ten thousand' and [ma'noo] 'shark, generic', [a'rooha] 'compassion' and [aro'ffaa] 'underside of chin', etc. Note that long and short vowels do not show differences in quality, and a long vowel is acoustically almost twice as long as its short counterpart. However, the 'non-past' verbal particle /e/ is lengthened before a bimoraic word except for words which contain geminate consonants resulted from vowel deletion (see below); this is in contradicition with suggested analysis. Grammatical particles are mostly unstressed, even if they contain a long vowel.

\section{Takuu geminate consonants}

Every Takuu consonant possesses its geminate counterpart. The bulk of apparent minimal pairs for geminate consonants is explicitly attested. Importantly, in Takuu a lexical word is always attested as part of either a noun phrase or a verb phrase, that is to say, following either determiners or tense-aspect-mood markers. Therefore, only noun phrases and verb phrases as a whole can be considered as minimal pairs. Because of this, below I list examples of shortest possible natural phrases, i. e. including the articles te 'definite, sg.', naa 'definite, pl.', verbal markers, and so on.
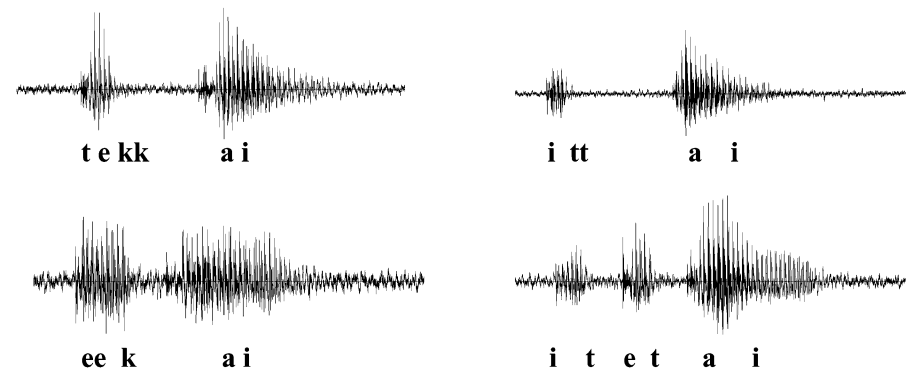

Figure 2. Oscillograms of Takuu minimal pairs with contrasting plain and geminate consonants (Speech Analyzer 3.1; one-second intervals): [te 'kkai] 'the tale', [ee 'kai] 'he eats', [i 'ttai] 'on the shore (short form)', [i te 'tai] 'on the shore (long form)'. Additional Takuu oscillograms and spectrograms can be found in on-line supplementary materials. 


$\begin{array}{llll}\text { [te 'paa] } & \text { 'pearl oyster' } & \text { [te 'ppaa] } & \text { 'flat rock' } \\ \text { [naa 'taa] } & \text { 'styles of canoe design' } & \text { [naa 'ttaa] } & \text { 'bailers (of canoe)' } \\ \text { [naa 'kai] } & \text { 'food, tubers' } & \text { [naa 'kkai] } & \text { 'fables' } \\ \text { [te 'nehu] } & \text { 'a kind of fish, used for bait' } & \text { [te 'nnehu] } & \text { 'stonefish' } \\ \text { [ee 'miti] } & \text { 's/he dreams' } & \text { [e 'mmiti] } & \text { 'he sucks (his mother's breast)' } \\ \text { [naa 'vare] } & \text { 'slime (of fish)' } & \text { [naa 'vvare] 'drunkards' } & \text { 'drung } \\ \text { [ee 'haa] } & \text { 'four' } & \text { [ee 'ffaa] } & \text { '(an egg) hatches' } \\ \text { [te 'sura] } & \text { 'hole (in a net)' } & \text { [te 'ssura] } & \text { 'slater' } \\ \text { [te 'luu] } & \text { 'a type of song' } & \text { [te 'lluu] } & \text { 'sheltered area' } \\ \text { [te 'ria] } & \text { 'nit' } & \text { [te 'llia] } & \text { 'edible shellfish sp.' }\end{array}$

Phonological contexts where geminate consonants are attested

Although double consonants are frequent, they are attested in contexts that are predictable either from the grammatical or the historical points of view.

Rule 1. Double consonants occur in words with initial /t/ that follow the definite article /te/. The /e/ in /te/ is elided and the initial / $t /$ of the following word is doubled. Both forms are found in free variation.

$\begin{array}{ll}\text { [te 'tama } \sim \text { 'ttama] } & \text { 'the person' } \\ {[\text { i te 'tai } \sim \text { i 'ttai] }} & \text { 'in the sea' } \\ \text { [te 'tono } \sim \text { 'ttono] } & \text { 'the mangrove' } \\ \text { [te 'tuna } \sim \text { 'ttuna] } & \text { 'the moray eel' } \\ \text { [te tee'voo } \sim \text { ttee'voo] 'the table' } \\ \text { [te ti'pua } \sim \text { tti'pua] } & \text { 'the spirit' }\end{array}$

Rule 2. Similarly, the specifier particle / ko/ and the particle /soko/ 'alone' behave the same way in combination with the personal pronouns /koe/ '2nd sg.', /koorua/ '2nd dl.' and /kootou/ '2nd pl.'.

[ko 'koe 'kkoe] 'you (sg.)'

[soko koo'rua sokkoo'rua] 'only you (dl.), yourselves (dl.)'

Rule 3. Similarly, ['tonu] 'directly, very' yields [i loto 'tonu i lo'ttonu] 'in the centre (of)', if combined with ['loto] 'inside'.

Rule 4. The 'causative, similative' suffix /haka-/ is optionally shortened to /hak-/ before stems which begin with $/ k /$, resulting in a geminate.
['kaa] 'sharp' $\rightarrow$
[ha'kkaa haka'kaa] 'to sharpen'
['kanu] 'pattern' $\rightarrow$
[ha'kkanu haka'kanu] 'to decorate with a pattern'
*faka-kii 'throat' (lit. 'causing to speak') $\rightarrow$
[ha'kkii haka'kii] 'larynx'
*kupu 'south (wind)' $\rightarrow$ [a'nake ha'kkipu a'nake haka'kipu] 'south- east wind direction' (syn. ['kipu ha'kaa'nake])
[koro'koro] 'long straight lines in the sky' $\rightarrow \quad$ [ha'kkoro haka'koru] 'to gather (of clouds)' 
['kohu] 'smoke (as seen from far away)' $\rightarrow$

[kuru'miti] 'to crave for food' $\rightarrow$ [ha'kkohu haka'kohu] 'to burn smth. so as to produce smoke' [hakkurumi'tia hakakurumi'tia] 'to be forced to crave for food, pass.'

The word hakkaa'toa 'completely' is not accepted in its non-reduced form which contrasts with the etymologically related word hakkaa'toa hakakaa'toa 'to complete'. It is the only word for which an expanded form is not attested.

Rule 5. In Takuu most verbs agree in number with their plural subjects by reduplicating the penultimate syllable of the stem. When the syllable is reduplicated, the vowel is elided, forming an initial consonant. However, among older speakers the syllabic reduplication is sometimes retained (cf. Moyle 2011: 11-12).

$\begin{array}{ll}\text { [e a'puru] '(it) sinks' } & \text { [e a'ppuru] '(they) sink' } \\ \text { [ee 'keri] '(he) digs' } & \text { [e 'kkeri] '(they) dig' } \\ \text { [ee 'mori] '(he) is slow' } & \text { [e 'mmori] '(they) are slow' } \\ \text { [e ma'nia] '(he) is slippery' } & \text { [e ma'nnia] '(they) are slippery' } \\ \text { [ee 'vusu] '(he) boxes' } & \text { [e 'vvusu] '(they) box' } \\ \text { [ee 'horo] '(he) swallows' } & \text { [e 'fforo] '(they) swallow' } \\ \text { [e ma'sike] '(he) stands up' } & \text { [e ma'ssike] '(they) stand up' } \\ \text { [e ka'rana] '(he) calls out' } & \text { [e ka'llana] '(they) call out' }\end{array}$

Rule 6. To indicate repeated action, the final two syllables of the word are reduplicated. With plural subjects, there is double reduplication (cf. Moyle 2011: 11-12).

[ee 'kata] '(he) gives a laugh' [e 'kkata] '(they) give a laugh'

[ee 'toro] '(he) collects shellfish (one)' [e 'ttoro] '(they) collect shellfish (one)'

[ee 'hatu] '(he) composes (a story)' [e 'ffatu] '(they) compose (a story)' [e kata'kata] '(he) laughs (repeatedly)' [e kata'kkata] '(they) laugh (repeatedly)'

[e toro'toro] '(he) collects shellfish (repeatedly)' [e toro'ttoro] '(they) collect shellfish (repeatedly)'

[e fatu'fatu] '(he) composes stories (repeatedly)' [e fatu'ffatu] '(they) compose stories (repeatedly)'

Rule 7. There are no $C_{1} V_{1} C_{1} V_{1}$ words attested in Takuu, but $C_{1} C_{1} V_{1} V_{1}$ words are common. It is easy to see that $C_{1} C_{1} V_{1} V_{1}$ words are derived from Proto-Polynesian $C_{1} V_{1} C_{1} V_{1}$ words ${ }^{3}$.

['kkii] 'food eaten with another food as relish' $\leftarrow{ }^{*} k i k i$ id.

['llee] 'fly (of birds), swim (of fish)' $\quad$ * *lele id.

['mmii] 'urinate, urine'

$\leftarrow{ }^{*}$ mimi 'urinate'

['nnoo] 'brown noddy (Anous stolidus)'

$\leftarrow{ }^{*}$ yoyo id.

['ppee] 'butterfly (generic)'

$\leftarrow{ }^{*}$ pepe id.

['ttoo] 'blood'

$\leftarrow{ }^{*}$ toto id.

['ssii] 'edible shellfish sp.'

$\leftarrow{ }^{*}$ sisi 'univalve shellfish'

${ }^{3} \mathrm{C}$ stands for any consonant; $\mathrm{V}$ stands for any vowel. 
Moreover, singular subject and plural subject frequentative verb forms show that in derivation Rule 5 " $\mathrm{C}_{1} \mathrm{~V}_{1} \mathrm{C}_{1} \mathrm{~V}_{1} \mathrm{C}_{2} \mathrm{~V}_{2}>\mathrm{C}_{1} \mathrm{C}_{1} \mathrm{~V}_{1} \mathrm{C}_{2} \mathrm{~V}_{2}$ " precedes Rule $6{ }^{\text {" }} \mathrm{C}_{1} \mathrm{~V}_{1} \mathrm{C}_{1} \mathrm{~V}_{1}>\mathrm{C}_{1} \mathrm{C}_{1} \mathrm{~V}_{1} \mathrm{~V}_{1}$ ".

[hakale'llere], not [hakallee'llee]
['ttoto], not [to'ttoo]
[hakanu'nnunu], not [haka'nnuu'nnuu]

Cf. also: [no'nnono] 'human brain' 'fly (a kite)'

'bleed, be bloody'

'continually making a rumbling sound (as of a stomach), cf. 'nnuu 'make a whirring or vibrating noise, whimper'

$\leftarrow{ }^{*}$ lolo 'brain matters'.

Note that compound words with $\mathrm{C}_{1} \mathrm{~V}_{1} \mathrm{C}_{1} \mathrm{~V}_{1}$ sequences do not follow this rule.

[hana'papa], not [hana'ppaa]

[kakaa'mata], not [kkaa'mata]

[maa'sisi], not [maa'ssii]

[pepe'au], not [ppee'au] 'inedible mollusc sp.', cf. ['ppaa] 'pearl oyster'

'to begin, freq.', cf. ['kaamata] 'to begin'

'cigarette lighter (Tok Pisin)'

'foam on the sea, suds', cf. [pe'au] 'wave'

$\mathrm{C}_{1} \mathrm{~V}_{1} \mathrm{C}_{1} \mathrm{~V}_{1}$ sequences are permitted if followed by two or more syllables, which is only possible in compounds, derivations and loans. In such contexts, they are not transformed into double consonants.

[akaka'ssia], not [akkaa'ssia]

[koko'rosi], not [kkoo'rosi]

[pupu'kau], not [ppuu'kau]

[rurupe'ia], not [lluupe'ia] freq., pass. from ['aa'kasi] 'to kick'

'cockroach'

'whole coconut shell with a small hole but without meat'

'fish sp.'

Rules 2 and 3 are similar to Rule 5, but involve grammatical words rather than derivational morphemes. Rules 1-5 (with minor variations) but not Rule 6 are also found in Kapingamarangi (Lieber, Dikepa 1974), Nukeria and Nukumanu (author's own fieldwork data of 2013), Nukuoro (Carroll, Soulik 1973), Sikaiana (Donner 1987) and Tuvalu (Milner 1958, Besnier 2000). Remarkably, Luangiua shows reduced vowels rather than double consonants in the above-listed contexts (Salmond 1974: 223)4.

\section{Do geminate consonants represent independent phonological segments in Takuu?}

It is evident that double consonants occur under easily recognisable conditions in Takuu, even though many apparent minimal pairs for geminate consonants are attested in the language. Moreover, we can formulate a general rule: elision of the vowel happens in certain environments which favour vowel reduction, such as the definite article te, the pre-stressed vowel and the causative suffix haka-. ${ }^{5}$ Grammatical and phonological descriptions of the language would benefit from an analysis of double consonants as surface representation of underlying sequences

\footnotetext{
${ }^{4}$ Anna Salmond defines these vowels as devoiced, but transcribes them as [ə].

${ }^{5}$ Even Hovdhaugen (1992) reports on extra-short vowels of partially reduplicated syllables in Samoan.
} 
of phonemes rather than independent phonological segments. $A$ few $C_{1} C_{1} V_{1} V_{1}$ and $C_{1} C_{1} V_{1} C_{2} V_{2}$ Takuu words can be understood as underlying $C_{1} V_{1} C_{1} V_{1}$ and $C_{1} V_{1} C_{1} V_{1} C_{2} V_{2}$ sequences.

['ffine] 'woman'

['lloo] 'coconut cream'

['vvee] 'grass, lawn' $\leftarrow$ pNP *fafine, cf. [haa'hine] 'women'

$\leftarrow$ pNP *lolo id.

$\leftarrow$ pNP *wewe 'rubbish, refuse'

The majority of $C_{1} C_{1} V_{1} C_{2} V_{2}$ verbs have a frequentative or intensive semantic aspect.

['kkiva] 'be shiny'

['mmaha] 'be heavy'

['vvoro] 'to stab through, hurl (a spear)' cf. [kiva'kiva] 'id., freq.'

cf. [hakamaha'mmaha] 'imper. freq. caus.'

cf. [voro'sia] 'id., pass.'

Again, in case of verbs it is possible to find derived and etymologically related forms which show consonants separated by vowels rather than geminated.

According to Richard Moyle (2011: 7), whereas most Takuu speakers utilise double consonants, a very small number of people pronounce the same words with a vowel between those consonants: [sa'samu] rather than ['ssamu] 'beat'. My own consultants pronounced a couple of words with non-geminated consonants: [na'nahu] rather than ['nnahu] 'ashes', but cf. pNP *gaa-lafu 'charcoal'. The same happened to my Nukeria consultants: [hi'hipa] 'a sea creature similar to jellyfish' rather than ['hhipa], [ro'roi] 'to prepare food with coconut cream' rather than ['rroi], etc. and my impression is that non-geminated forms are used for words which a particular speaker has not used for many years; in trying to remember such words, people always remember the expanded, or, more accurately, the underlying forms.

Expanded forms also occasionally occur in songs (see also Moyle 2011: 7).

['nono] poetic for ['nnoo] 'noddy'

['lele] poetic for ['llee] 'to fly'

[ki'kila] poetic for [saa'kila] 'to look or glance once out of the corner of one's eye'

The same phonetic process is found in traditional Nukeria songs, including songs in fables (author's own fieldwork data of 2013). Three alternative explanations for this poetic lack of gemination can be offered. First, expanded forms are outwardly archaic, corresponding to their Proto-Polynesian forebears. Second, they can provide an additional syllable when one is required to fill up a prescribed duration for a poetic line. Third, double consonants are not perceived when sung; consequently, the double consonant words would become incomprehensible in songs. Another phonetic marker of the Takuu poetic language is that [a] vowels frequently, but not identically or consistently, shift to [o] (Moyle 2007: xxi). The same [a] to [o] shift is attested in Nukumanu (Johnstone, Feinberg 2006) and Nukeria songs (author's own fieldwork data of 2013).

To sum up, geminated consonants do not have phonemic status in Takuu, Nukeria, Nukumanu and Sikaiana, though Takuu is on the verge of incorporating geminated consonants in its phonological system, since the geminate counterpart of [r] is [1l] and the geminate counterpart of [h] is [ff]. In Nukeria, Nukumanu and Sikaiana all single and double consonants show the same quality; acoustically they differ in duration only. The fact that Takuu geminate consonants are twice longer as their plain counterparts also supports the suggestion that geminate consonants do not represent independent phonological segments. Note that the 'non-past' verbal particle /e/ is lengthened before $\mathrm{C}_{1} \mathrm{VC}_{2} \mathrm{~V}$ bimoraic words, but not before $\mathrm{C}_{1} \mathrm{C}_{1} \mathrm{VC} \mathrm{C}_{2} \mathrm{~V}$ bimoraic words resulted from deletion of a vowel between two identical consonants. 
No borrowings show double consonants, but this may be an accidental gap in the lexicon, since double consonants are expected in words with the structure $C_{1} V_{1} C_{1} V_{1} C_{2} V_{2}$ and $C_{1} V_{1} C_{1} V_{1}$.

\section{Distributions of Takuu liquids}

According to my principal consultant, younger speakers do not pronounce the [r] words correctly, they tend to substitute [r] for [1] everywhere. He also mentioned that a few elders on Takuu pronounce [r] everywhere. It is difficult to verify these statements. Below I will discuss the data that I have gathered with my consultant and the data from Richard Moyle's dictionary (2011). Moyle (2011: 8-9) writes: "Since [h] and [r] are the dominant forms, I have entered all these forms under those letters, listing as variants those words for which [f] or [1] are claimed by some Takuu to be more correct". My consultant is male and about 50 years old; I assume that Moyle's principal consultants were of the same age sex group. I was unable to find a minimal pair contrasting [1] and [r] in the speech of the same speaker, but I did find one example in Moyle 2011: ['lau] 'leaf, sg.' ['rau] 'leaf, pl.'. My consultant, however, asserts that both pronunciations ['lau] and ['rau] are correct.

Moyle (2011: 8-9) also mentions that some speakers use [f] and [1] as opposed to [h] and [r] in certain words as a means of emphasis, being quite aware that this differs from common usage. I have not studied or observed any such use of geminate consonants.

Remarkably, in Takuu [1l] is the only geminate counterpart for both [1] and [r] (see above). Geminated consonants are less susceptible to sound changes in comparison with their plain counterparts; for example, Takuu $f f V_{1}$ corresponds to Proto-Polynesian ${ }^{*} f V_{1} f V_{1}$, while ProtoPolynesian ${ }^{*} V C V$ corresponds to Takuu $h V C V$, although some speakers accept both variants. Thus, it is possible to suggest that [11] reflects an archaic realisation of the segment. This reconstruction is hypothetical, but it should be noted that Takuu [l] and [r] derive from Proto-Polynesian *l [Biggs 1978; for a recent summary on the question see Marck 2000: 120-124, 237-247]. The exact phonetic realisations of Proto-Polynesian ${ }^{*} l$ and ${ }^{*} r$ are subject to speculation. However, it is true that a sound change like $|r| \rightarrow \emptyset$ is more natural and common in comparison with $/ l \mid \rightarrow \emptyset$. This is an argument in favour of the widely accepted reconstructions for Proto-Polynesian ${ }^{*} l$ and ${ }^{*} r$, since ${ }^{*} r$ becomes $\emptyset$ in Tongan and Niue, while in Nuclear Polynesian languages ${ }^{*} r$ merges with $*$. Richard Moyle (personal communication, 2014) has mentioned to me that in the 1994-2009 period there were fewer than ten people on Takuu, all of them elderly, who regularly used [f] and [1].

Rule $1:{ }^{*} l \rightarrow r,{ }^{*} l l \rightarrow l l$.

It should be noted that the sound change $r \rightarrow l$ and vice versa is one of the most common types of sound change found in the world's languages and one that is quite easily explained from the physiological point of view.

According to my consultant, the following items are not subject to variation: [hakale'llere] 'to try to fly (a kite)', [le'llee] 'swimming about (pl.)', [lea'llea] 'be possessed by a spirit (freq.)', [hakali'lliri] 'to tease', [hakalu'lluru] 'to take shelter (pl.)', [matali'lliri] 'versatile', [lo'llosi] 'protect (pl.)', cf. [roo'rosi] 'id. (sg.)', etc. In other words, the segment agrees with the following double consonant in the derived form.

Rule 2: ${ }^{*} r V_{1} l l V_{1} V_{1} \rightarrow l V_{1} l l V_{1} V_{1},{ }^{*} r V_{1} l l V_{1} r V_{1} \rightarrow l V_{1} l l V_{1} r V_{1}$

This sound change is natural and can be described as assimilation, induced by a kind of lateral harmony spreading leftwards in the word. 
Sometimes, the same root shows different realizations of the segment in derived forms and compounds. Sometimes, the same root shows two different liquids.

[ee 'lua] 'two', but [sinahuru maa rua] 'twelve $(10+2)$ ', [matarua maa 'rua] 'twenty $(2 \times 10+2)$ ' [i 'laro] 'below'

[laa'raa] 'dorsal fin (of sharks)', reduplication

[laa'rona] 'pass., be supported'

[la'uru] 'hair (on one's head)'

[loto'roto] 'centre portion of a channel or passage through the reef which is unobstructed by rocks', reduplication

My informants accept [i 'raro], [raa'raa], [raa'rona], [roto'roto], [ra'uru], but not [ee 'rua]. This may be a hint that realisation of the segment depends on its position within the word and on the quality of the accompanying vowel. A statistical analysis of the lexical entries in Moyle's dictionary allows to formulate the following rules (the reason for separating Rule 3 from Rule 4 is given below):

Rule 3: * $r \rightarrow$ l/\#_a.

Rule 4: ${ }^{*} r \rightarrow l / \# \_$.

\begin{tabular}{l|c|c|c|c|c|c|c|c|c|c}
\hline & li & ri & le & re & la & ra & lo & ro & lu & ru \\
\hline /\#_ & 9 & 51 & 7 & 33 & 183 & 65 & 64 & 24 & 6 & 47 \\
\hline /_\# & 1 & 265 & 5 & 202 & 51 & 235 & 47 & 178 & 1 & 196 \\
\hline totals: & 10 & 316 & 12 & 235 & 234 & 300 & 111 & 202 & 7 & 243 \\
\hline
\end{tabular}

Some of the examples are as follows:

['rima] 'arm, hand'

[riri'aki] 'to swing on a swing'

[rehu'rehu] 'small rain cloud'

['rei] 'whale tooth'

['rue] 'men's dance type'

[rutu'rutu] 'tree sp.'

A number of words that contain final syllables -la and -lo violate Rule 3. However, the appearance of such syllables depends on the vowel that they follow.

\begin{tabular}{c|c|c|c|c|c|c}
\hline & $\mathrm{i}_{-}$ & $\mathrm{e}_{-}$ & $\mathrm{a}_{-}$ & $\mathrm{o}_{-}$ & $\mathrm{u}_{-}$ & $-^{\#}$ \\
\hline $\mathrm{li}$ & 9 & 0 & 19 & 4 & 1 & 1 \\
\hline le & 22 & 3 & 13 & 1 & 0 & 5 \\
\hline la & 109 & 64 & 26 & 2 & 6 & 51 \\
\hline lo & 146 & 47 & 6 & 16 & 3 & 47 \\
\hline lu & 10 & 2 & 4 & 0 & 7 & 1 \\
\hline
\end{tabular}


Some examples:

['pela] 'black mud, swamp'

[ha'relo] 'coral, generic'

['ffelo] 'yellow'

[ma'tila] 'stout type of bamboo used as tuna-fishing rod'

[maa'pilo] 'fish sp.'

It must be noted that the sequences $i / \_a, o$ and $e / \_a, o$ in non-final position also trigger the same sound change.

[ilaa'motu] 'classificatory mother's brother, sister's children'

[i'loa] 'to know'

[tee'laa] 'that over there (dem. pron.)'

Rule 5: ${ }^{*} r \rightarrow l / i, e \_a, o$.

A meticulous analysis of the distribution between $l$ and $r$ that takes into account both the preceding and the following vowels allows to suggest another, less evident, rule. ${ }^{6}$ Compare the following two tables:

\begin{tabular}{|c|c|c|c|c|c|c|}
\hline & $i_{-}$ & $\mathrm{e}_{-}$ & $a_{-}$ & $\mathrm{O}_{-}$ & $u_{-}$ & $\#_{-}$ \\
\hline li & 9 & 0 & 19 & 4 & 1 & 9 \\
\hline le & 22 & 3 & 13 & 1 & 0 & 7 \\
\hline la & 109 & 64 & 26 & 2 & 6 & 183 \\
\hline lo & 146 & 47 & 6 & 16 & 3 & 64 \\
\hline \multirow[t]{2}{*}{ lu } & 10 & 2 & 4 & 0 & 7 & 6 \\
\hline & $\mathrm{i}_{-}$ & $\mathrm{e}_{-}$ & $a_{-}$ & $\mathrm{O}_{-}$ & $u_{-}$ & \#_ \\
\hline ri & 291 & 45 & 422 & 86 & 302 & 51 \\
\hline re & 3 & 250 & 322 & 60 & 113 & 33 \\
\hline ra & 5 & 1 & 727 & 121 & 208 & 65 \\
\hline ro & 4 & 1 & 320 & 355 & 39 & 24 \\
\hline $\mathrm{ru}$ & 6 & 36 & 252 & 54 & 380 & 47 \\
\hline
\end{tabular}

Rule 6: ${ }^{*} r \rightarrow l / i \_, u$.

The rules formulated above cover almost all the data in Richard Moyle's dictionary. This is surprising, since his dictionary presents data from various speakers, gathered by Barbara Moir and Irwin Howard during 1976-1979, including different pronunciations of the same word. Incidentally, the idiosyncratic forms [ee 'lua] and [naa 'rau] may also be explained by the suggested rules.

${ }^{6}$ I am grateful to Evgenia Korovina for this observation (personal communication, 2014). 


\section{A change in progress}

It is easy to see that we are not dealing here with a single sound change, but rather with a cascade of interrelated sound changes, chronologically ordered and conditioned by different phonological environments.

The sound change $r \rightarrow l$ is natural; likewise, it is also natural for double 'fortis' consonants to preserve more archaic mechanisms of realisation. Rule 2 seems to follow common articulatory tendencies. Among other things, it may have been triggered by etymological leveling, since the general canons in the language for $C_{1} V_{1} C_{2} V_{2}$ reduplicated forms are $C_{1} C_{1} V_{1} C_{2} V_{2}$ 'plural subject, frequentative (sg.)' and $\mathrm{C}_{1} \mathrm{~V}_{1} \mathrm{C}_{2} \mathrm{~V}_{2} \mathrm{C}_{1} \mathrm{C}_{1} \mathrm{~V}_{1} \mathrm{C}_{2} \mathrm{~V}_{2}$ 'frequentative (pl.)'. Rule 2 could also have motivated Rule 3, since $/ a /$ is four times more frequent in Polynesian than any other vowel; therefore, the sequences /lalla/ and /lallara/ were better statistically represented in comparison with /lilli/ and /lilliri/.

\begin{tabular}{l|c|c|c|c|c}
\hline & \#RiCV & \#ReCV & \#RaCV & \#RoCV & \#RuCV \\
\hline Number of head entries & 32 & 20 & 122 & 41 & 23 \\
\hline percentage of all \#RVCV & $13,5 \%$ & $8,4 \%$ & $51,3 \%$ & $17,2 \%$ & $9,6 \%$ \\
\hline
\end{tabular}

Notes: 1. Both [1] and [r] are counted for R; \#llVV are counted as \#RVRV. 2. Derived forms, obsolete words, evident loanwords and nominal compounds, such as, e.g., fish names and plant names, are excluded from the calculations.

The phonetic similarity between [a] and [o] might be a reason for extending Rule 3 to the [ro] sequences; hence, Rule 4. Furthermore, Rule 5 is a conditioned extension of Rule 4, and Rule 6 can also be explained as a conditioned extension of Rule 5. Rules 3, 4, 5 and 6 are important in showing that the direction of change is from [r] to [l] and not the other way around. If my consultant's statement about younger speakers is correct, the different $r \rightarrow l$ changes (Rule 2-6) are extended to all the contexts where [r] is found, but it should be kept in mind that I am depending on his statement in making this suggestion. Remarkably, this final rule (Rule 7: ${ }^{*} r \rightarrow l$ ) eclipses Rules 2-6 and forces us to regard the sound change in progress as a simple $r \rightarrow l$ development, unless we pay attention to those distribution patterns that are found in the speech of middle-aged speakers.

Interestingly, Irwin Horward's data from 1976-1979 show the same distributional patterns for [1] and [r] (Barnard 1976: 110, 116, 98, 104, 123; Howard 1981: 111-114; Moyle 2011: entries marked with $\mathrm{IH}$ ). Below we list all the words with [1] and [r] that belong to the Swadesh 200-wordlist as originally published in Bayard 1976.

$\begin{array}{llll}\text { hakallika } & \text { bad } & \text { ttoro } & \text { rub (body) } \\ \text { kiri } & \text { bark of tree } & \text { kelekele } & \text { sand } \\ \text { tasi } & \text { big } & \text { taratara } & \text { say (or speak) } \\ \text { lari } & \text { black } & \text { araara } & \text { scratch (body) } \\ \text { uri } & \text { child } & \text { kiri } & \text { skin } \\ \text { tamariki } & \text { cold } & \text { lani } & \text { sky } \\ (\text { sau-)kamalli } & \text { lapono } & \text { smooth (vb.) } \\ \text { keri } & \text { dig } & \text { araa } & \text { some } \\ \text { kerekere } & \text { dirty } & \text { saavare } & \text { spit } \\ \text { kautarina } & \text { ear } & \text { raakau } & \text { stick } \\ \text { kerekere } & \text { earth } & \text { raa } & \text { sun } \\ \text { karamata } & \text { eye } & & \end{array}$




$\begin{array}{llll}\text { huruhuru } & \text { feather } & \text { fura } & \text { swell } \\ \text { lima } & \text { five } & \text { teelaa } & \text { that (away from speaker) } \\ \text { lele/llee } & \text { fly } & \text { ikilaa } & \text { there (away from speaker) } \\ \text { hua(-raakau) } & \text { fruit } & \text { raatou } & \text { they } \\ \text { taukareka } & \text { good } & \text { mattoru } & \text { thick (of solids) } \\ \text { moanauri } & \text { green } & \text { tolu } & \text { three } \\ \text { rauru } & \text { hair } & \text { alelo } & \text { tongue } \\ \text { rima } & \text { hand } & \text { raakau } & \text { tree } \\ \text { lono } & \text { hear } & \text { fuli } & \text { turn (around) } \\ \text { tataru } & \text { hunt (chase) } & \text { lua } & \text { two } \\ \text { iloto } & \text { in } & \text { lualua } & \text { vomit } \\ \text { iloa } & \text { know } & \text { (sa-)sare } & \text { walk } \\ \text { ora } & \text { live (alive) } & \text { vvela } & \text { warm (or hot) } \\ \text { pukua/laanutu } & \text { mouth } & \text { para } & \text { wet } \\ \text { taupiri } & \text { near } & \text { llaha } & \text { wide } \\ \text { telaa } & \text { other (another kind) } & \text { ssoro } & \text { wipe } \\ \text { soroki } & \text { pull (toward speaker) } & \text { felo } & \text { yellow } \\ \text { ara } & \text { road } & & \\ & & & \end{array}$

Note: instances of $l$ and $r$ which are in agreement with the proposed rules are shadowed; the ones violating the rules are underlined.

\section{Historical and sociolinguistic implications}

Upon first glance, the random distribution of [1] and [r] in Takuu lexicon suggests that we are dealing with a sound change in progress; this suggestion is favoured by the fact that older speakers tend to have more [r] sounds and the younger ones less. However, it is also strongly countered by the insistence of some of the speakers that only [1] is acceptable in some words. This is a challenge for the theory of sound change, since a sound change in progress implies free variation in the realisation of a phoneme. It is also a challenge for historical linguistics as the practice of reconstructing proto-languages. In fact, the change in question in Takuu is not a change in progress, but a chainwise series of changes that involve the same phoneme and trigger one another. Ironically, this series of interrelated sound changes results in the same situation in which it started out, namely, when all the liquids in the language become laterals. One could say that Rule 7 abolishes Rule 1 and describe it as $l \leftrightarrows r$.

The sounds [r] and [1] are found in variation in Luangiua (Hogbin 1930), as well as Anuta (Feinberg 1977: 10-12), Kapingamarangi (Elbert 1950: 8, 13), Tuvalu (Besnier 2000: 609-610), Rennell and Bellona (Elbert 1962) and Ni'ihau Hawai'ian (Elbert, Pukui 1985: 23-25). Raymond Firth (1963) has demonstrated that some $40 \%$ of relatively rare words with /l/ in Tikopia show negative and obscene associations, even though both the common $/ r /$ and the rare $/ l /$ reflect Proto-Nuclear-Polynesian * $l$. Nukeria and Nukumanu also show variation in the realisation of $\mathrm{pNP}^{*} l$ (see more on this below). Irregular reflexes of Proto-Polynesian ${ }^{*} l$ and ${ }^{*} r$ are well-known in literature (Biggs 1978; Marck 2000; Gell-Mann, Peiros, Starostin 2008; Belikov 2006: 32 etc.).

According to my Nukumanu consultant (male, about 40 years old), the sound change $r \rightarrow$ $l$ is nearing completion in Nukumanu. However, my own Nukumanu wordlist and an unpublished Nukumanu lexicon of 2000 (Feinberg n.d.) show similar distribution patterns for [1] and 
[r]: Rule $1\left({ }^{*} l \rightarrow r,{ }^{*} l l \rightarrow l l\right)$; Rule $3\left({ }^{*} r \rightarrow l /{ }^{*} \_a\right)$; Rule $4\left({ }^{*} r \rightarrow l / \# \_o\right)$. It is difficult to ascertain if Rule $5\left({ }^{*} r \rightarrow l / i, e_{-} a, o\right)$ and Rule $6\left({ }^{*} r \rightarrow l / i_{-} e, u\right)$ are active in Nukumanu, because the lexicon in question is relatively short. It is evident that Takuu and Nukumanu share the on-going changes. Nukumanu lies $275 \mathrm{~km}$ east of Takuu and about $50 \mathrm{~km}$ north of Luangiua; Nukeria lies $275 \mathrm{~km}$ northwest-by-west from Takuu (Bayard 1976: 15). However, speakers of Luangiua, Takuu (also known as Nukutoa), Nukumanu, and Nukeria are in intimate contact from time immemorial, as, for example, many Nukumanu and Takuu speakers eventually settled down on Nukeria, and Takuu people know many songs of Nukumanu origin and vice versa. Nukumanu language is particularly close to Luangiua (author's fieldwork data of 2013). Fortunately, some Nukumanu texts had earlier been collected by German scholars (Safert, Damm 1929: 385-387, 407-408, 437-439, 443-460), and they happen to show only a couple of instances of [r], allowing us to posit a terminus post quem for Rule 1 above. The issue of the distribution of liquids in Nukumanu begs further investigation.

A similar situation is found in Nukeria. My Nukeria wordlist contains about 760 lexical entries which show both $r$ and $l$. In compiling it, I have included all the variants with [1] and [r] that I heard. I have excluded evident loanwords and compounds from my calculations, and have counted variants with [1] and [r] as independent entries, if both were attested.

\begin{tabular}{|c|c|c|c|c|c|c|}
\hline & $\mathrm{i}_{-}$ & $\mathrm{e}_{-}$ & $a_{-}$ & $\mathrm{O}_{-}$ & $u_{-}$ & $\#_{-}$ \\
\hline li & 1 & 1 & 0 & 0 & 0 & 1 \\
\hline le & 2 & 1 & 0 & 0 & 0 & 0 \\
\hline la & 7 & 11. & 0 & 0 & 0 & 17 \\
\hline lo & 14 & 3 & 1 & 1 & 0 & 2 \\
\hline \multirow[t]{2}{*}{ lu } & 1 & 0 & 0 & 0 & 0 & 3 \\
\hline & $\mathrm{i}_{-}$ & $\mathrm{e}_{-}$ & $a_{-}$ & $\mathrm{O}_{-}$ & $u_{-}$ & $\#_{-}$ \\
\hline ri & 41 & 3 & 37 & 5 & 27 & 10 \\
\hline re & 1 & 33 & 27 & 7 & 8 & 11 \\
\hline ra & 1 & 1. & 57 & 14 & 29 & 30 \\
\hline ro & 1. & 3 & 24 & 34 & 2 & 20 \\
\hline $\mathrm{ru}$ & 0 & 6 & 22 & 4 & 35 & 11 \\
\hline
\end{tabular}

Nukeria shares some rules with Takuu: Rule $5\left({ }^{*} r \rightarrow l / i, e \_a, o\right)$ and Rule $3\left({ }^{*} r \rightarrow l / \# \_a\right)$, but remarkably not Rule $4\left({ }^{*} r \rightarrow l / \# \_o\right)$. We should note that these rules are active, and I have not heard of any unacceptable words with $r$. The double consonant in Nukeria is not $l l$, but $r r$. Note also that according to my Nukeria consultants (male, from 40 to 60 years old), the [1] sound is not a part of the original Nukeria language. Actually, an early Nukeria wordlist (Parkinson 147150) show several examples of $[1]^{7}$. One likely explanation is the particular phonetic realisation of Nukerian [r] which, to my ear, is an alveolar flap (as in Spanish); it might have been perceived as a lateral by Richard Parkinson. The implication is that Rules 1 and 2 are impossible in Nukeria. What we are dealing with here are shared on-going sound changes.

${ }^{7}$ Nuguria lexical data published by Georg Thilenius (1902: 84-95) was probably gathered on the Feads from a Liuangiua by origin and cannot be considered Nukeria. 
According to Nico Daams (personal communication, 2014), in today's Luangiua $/ l /$ and flap $/ r /$ are sometimes in free variation. Generally $/ r /$ occurs in common rapid speech, whereas $/ l /$ is typical of slower speech: kamali'i kamari'i 'child', malama marama 'clear', aloha aroha 'feeling of missing someone', etc. However, some words are never pronounced with $/ l /$ : sarau 'cat', kaupeara 'young man', koru 'three', varu 'eight'. Word-initially it is always /l/: lua 'two', lima 'five', etc. Luangiua data clearly show the kind of phonological complexity we deal with: there are two liquids in the Luangiua phonological system $-R_{1}$, which is realised either as [1] or as [r] and $R_{2}$, which is always realised as [r]; the opposition between $R_{1}$ and $R_{2}$ is neutralised in word-initial position as [1].

It is tempting to suggest that a similar complex set of phonological rules involving distribution between various age groups and possibly also depending on the sex of the speaker may underlie the anomalous distribution of the sounds [f] and [h] in Takuu that Richard Moyle writes about (2011: 8-9). Similarly, a change in progress involving [f], [s], and [h] and sometimes showing 'overcomplicated' distributions in the realisation of fricatives is found in many Polynesian languages: Anuta (Feinberg 1977: 8, 10-12), Kapingamarangi (Elbert 1950: 8), Luangiua (Hogbin 1930), Nukeria (author's fieldwork data), Rennell and Bellona (Elbert 1988: 8), Sikaiana (Donner 1987), Tokelau (Hooper 1996: 2), Tuvalu (Besnier 2000: 609-610), Vaeakau-Taumako (Næss, Hovdhaugen 2011: 41-44). Irregular behavior of *s and * $f$ in Polynesian languages is also well-known (Harlow 1998; Hooper 1996: 2; Hovdhaugen 2002; Marck 2000).

The two long lists above clearly show that Polynesian languages, in particular, Polynesian Outliers, are prone to circular sound changes $l \leftrightarrows r$ and $f \leftrightarrows h \leftrightarrows s$. This observation has two implications. First, Polynesian languages should probably not be subgrouped on the basis of sound changes involving $/ f /,|s /|, h /, \mid l /$ and $/ r /$, since they can hardly be diagnostic for establishing their internal relationships. Note that 'irregular' ${ }^{*} h$ and 'irregular' ${ }^{*} r$ constitute two main phonological arguments for establishing the Tongic branch of Polynesian languages that consists of just two languages - Tongan and Niue (Biggs 1978). Second, it is tempting to suggest that a complex set of interrelated rules operating in a language on two and more sounds can induce irregular developments in some sets, because, on the one hand, such complex sets of interrelated rules are attested in many Polynesian languages and, on the other hand, it is exactly the involved sounds that show irregular reflexes all across the family.

Assuming that a younger speaker may occasionally be unable to properly learn different phonetic rules which operate in different age-sex groups of his mother tongue, he will learn some words of his own language incorrectly. The scenario in question seems to be particularly likely in the situation when the number of speakers has been reduced to a couple dozen or less. In such a small community age and sex groups could not be clearly contrasted, so rules that differ based on various age-sex groups rules might be confused. Dramatic decrease of population regularly happened to the small island communities due to extremely limited food resources and living on isolated atolls far away from other peoples. According to Richard Parkinson (1907), at the beginning of the 20th century the number of Nukeria speakers was about 15, and the number of Takuu speakers about 20. Later the number of Takuu speakers was reduced to 12 (Moyle 2077: 18). It is also likely that in many cases the islands were originally populated by just a few immigrants (one canoe crew, for instance).

However, there is really no need to resort to the help of the 'dramatic-decreasepopulation' theory. The number of phonological environments is potentially infinite, meaning that the number of potential sound changes is also infinite. Assuming that 10 contextual sound changes were to take place in a language in 100 years, it would be difficult to formulate underlying rules and, more importantly, a comparative linguist would not probably bother him- 
self to try to search for such rules. 10 sound changes in 100 years are relatively slow rates compared to what is happening to Takuu today. ${ }^{8}$

An intriguing question is why Polynesian peoples would keep modifying the pronunciation of liquids and sibilants in circles for thousands of years. Over the course of my fieldwork I constantly witnessed lengthy discussions from Nukeria and Takuu people on what should be the correct pronunciation of a given sound and which word could be said to be "originally theirs", in the case of Nukeria speakers - which one belongs to Nukumanu and which one to Takuu. ${ }^{9}$ It was not me, but the islanders themselves who initiated these discussions. At first, I was quite skeptical about their statements, but eventually, upon consulting earlier sources, most of them turned out to be correct. Is it possible that talking all the time about the correct and incorrect pronunciation of a sound could 'hit up' sound changes which involve this sound?

Importantly, the usual context of talking about the right sounds and the right words always involves elders scolding younger people for speaking incorrectly. Like most other Polynesian cultures, Takuu, Nukeria, and Nukumanu are cultures of esoteric knowledge. According to the islanders, you can inherit knowledge of particular words, names for nights of the Moon, fish names, stories, songs, etc. only from your father, and no one will share secret knowledge outside of one's family. ${ }^{10}$ It is utterly shameful if somebody says: "how can you not know the nights of the Moon? why haven't you learned them from your father?" Although this sounds like a gross exaggeration, I was told that sometimes a person might decide to commit suicide after being addressed in that manner.

Cultural practices are inherited in the same way as lexical roots and phonological rules. Let us put it thus: if you were scolded by your father for speaking in a wrong manner, you will probably scold your own son, once you have one, for the same thing. If every elder that you were familiar with scolded younger peoples around for speaking in a wrong manner, you will do this with certainty. Polynesian Outliers are described as chiefdoms, that is to say, societies with social ranking that achieve political integration through an office of central leadership occupied by a chief (for a recent review on the subject see Scaglion 2012). The number of people on an atoll was often much smaller than is considered necessary for a chiefdom to exist, which would be at least around 1000 individuals (Earle 1997: 121). ${ }^{11}$ Polynesian Outliers inherited hierarchical political organization from their ancestors (see Kirch, Green 2001) and they could have also made use of alternative sources of power such as sorcery, access to secret knowledge, etc. Thus, the practice of scolding younger people and commoners for speaking in a wrong way could become an important instrument of political integration.

The ability of Nukeria, Nukumanu and Takuu speakers to reflect on facts of their own language is astonishing, in particular, taking into account that they are illiterate in their mother tongues. I will list just one conspicuous example of the many that I have collected. During my stay on Nukeria I heard words with [s] all the time; each time my consultants pronounce a word with [s], they add that it is not a Nukeria word, but a Takuu one. I was eager to

${ }^{8}$ In all honesty, I keep wondering myself how many contextual sound changes involving $/ r /$ and $/ l /$ in Takuu I could have missed while preparing this paper for publication.

${ }^{9}$ Many lexical entries in the Takuu dictionary (Moyle 2011) are marked as words of probable Nukumanu or Nukuria origin.

${ }^{10}$ In former days it was also possible in hare poe 'men's houses' - places where young bachelors had to sleep. These were places where men would gather to exchange stories, sing songs, talk about fishing techniques and drink alcoholic kareve 'coconut toddy'. Men's houses still exist on Takuu, but not on Nukeria.

${ }^{11}$ Estimations of population size for different Polynesian Outliers in different periods of time are given by Donn Bayard (1976: 14-18). 
disprove this statement. There was a Takuu teacher in the school, whom I once visited; on his class register, there was a title saying "Busuria". When I asked him why it is not "Buhuria" (Puhuria is the name of the island where the principal Nukeria villague is situated), I was immediately given an explanation: "We, Takuu people, know that Nukeria words have [h] when we have [s], so when pronouncing Nukeria words in Takuu we substitute [h] for [s]". Later, the statement turned out to be correct, according to an early Nukeria wordlist (Parkinson 147150). Possibly, this ability to reflect on facts of their own language is due to various reasons: all three groups live together, their languages all have a simple phonological structure and relatively little morphophonemics in operation, they are phonetically conservative and closely related, and their speakers pay particular attention to words and texts that have to do with the idea of secret knowledge. In this situation, an uncomfortable question for a linguist is which strategy he/she should choose when trying to develop a standard practical orthography.

\section{Conclusions}

The Takuu language shows a set of related ongoing sound changes that trigger each other in strictly defined phonological environments. These sound changes are taking place among four generations which co-exist in time; as a result, they may seem to represent a single sound change in progress. Similar sound changes can be easily overlooked and described as irregular. It is tempting to suggest that similar multiple sound changes might explain particular examples of irregular correspondences between Polynesian languages and beyond.

Supplementary materials (Takuu oscillograms and spectrograms plus sound files) are available from:

- http://jolr.ru/

- https://app.box.com/s/5fvcveltmaiayktnokm9

\section{References}

Bayard, Donn T. (1976) The cultural relationships of the Polynesian Outliers. Otago University Studies in Prehistoric Anthropology, No. 9. Dunedin: Department of Anthropology, University of Otago.

Belikov, V. I. (2006) Konvergentnye protsessy v lingvogeneze. Dissertatsiya v vide nauchnogo doklada, sostavlennaya na osnove opublikovannykh rabot, predstavlennaya $\mathrm{k}$ zaschite na soiskanie uchenoj stepeni doktora filologicheskikh nauk. Moskva: MGU.

Besnier, Niko (2000) Tuvaluan: A Polynesian language of the Central Pacific. Descriptive Grammars Series. London: Routledge.

Biggs, Bruce (1978) The history of Polynesian phonology. In: S. A. Wurm and Lois Carrington (eds.), Second International Conference on Austronesian Linguistics: Proceedings, Fascicle 2, Eastern Austronesian. Pacific Linguistics Series C, No. 61. Canberra: Australian National University: 691-716.

Carroll, Vern, and Tobias Soulik (1973) Nukuoro lexicon. PALI Language Texts: Polynesia. Honolulu: University of Hawai'i Press.

Donner, William W. (1987) Sikaiana vocabulary: Na male ma na talatala o Sikaiana. Honiara, Solomon Islands: published by the author through a grant from the South Pacific Cultures Fund of the Australian Government. See also online at http://www.sikaianaarchives.com/wp-contents/uploads/2012/06/Sikdict.pdf.

Earle, Timothy (1997) How chiefs come to power: The political economy in prehistory. Stanford, Calif.: Stanford University Press.

Elbert, Samuel H. (1988) Echo of a culture: A grammar of Rennell and Bellona. Honolulu: University of Hawai'i Press.

Elbert, Samuel H. (1962) Phonemic expansion in Rennellese. Journal of the Polynesian Society 71: 25-31. 
Elbert, Samuel H. (1950) Grammar and comparative study of the language of Kapingamarangi: Texts and wordlists. Typescript.

Elbert, Samuel H., and Mary Kawena Pukui (1985) Hawaiian grammar. 2nd edition. Honolulu, University of Hawaii Press.

Feinberg, Richard (1977) The Anutan language reconsidered: Lexicon and grammar of a Polynesian Outlier. 2 vols. HRAFlex Books. New Haven: Human Relations Area Files Press.

Feinberg, Richard (n.d.) Nukumanu lexicon. Revised List Prepared with input from Frank Lotivi, David Teaku, Sterlo Karoa, Greg Kaliva, Pinoa, Sereno, with Jerry Potau, Rachel Pinoa, Manahau Hatutahi, Francis Teneke, and Moomoa Areni. Unpublished manuscript. Pp. 36.

Gell-Mann, Murray, Ilia Peiros and Sergei A. Starostin (2008) Lexicostatistics compared with shared innovations: the Polynesian case. Aspects of Comparative Linguistics 3. Moscow: RSUH Publishers, Pp. 13-44.

Greenhill, Simon J., and Ross Clark (2011) POLLEX-Online: The Polynesian lexicon project online. Oceanic Linguistics 50: 551-558. See also: http://pollex.org.nz/.

Harlow, Ray (1998) Polynesian * $f$ and *s in the Eastern Polynesian Languages. Rongorongo Studies 8(2): 47-58.

Hogbin, H. Ian (1930) Notes on a grammar of the language of Ontong Java. Bulletin of the School of Oriental Studies 5: 823-852.

Hooper, Robin (1996) Tokelauan. Languages of the World/Materials 58. Munich: Lincom.

Hovdhaugen, Even (2002) Pileni - a Polynesian language with several Polynesian roots? Rongorongo Studies 12 (1): $22-28$.

Hovdhaugen, Even (1992) Phonetic vowel length in Samoan. Oceanic Linguistics 31(2): 281-285.

Howard, Irwin J. (1981) Proto-Ellicean. In: Jim Hollyman and Andrew Pawley (eds.), Studies in Pacific languages and cultures in honour of Bruce Biggs. Te Reo Monographs. Auckland: Linguistic Society of New Zealand, pp. 101118.

Johnstone, Jennifer, and Richard Feinberg (2006) From Oriori to the Everly Brothers: Observations on the music of Nukumanu. Journal of the Polynesian Society 115(4): 365-381.

Kirch, Patrick Vinton, and Roger Green (2001) Hawaiki, ancestral Polynesia: An essay in historical anthropology. Cambridge: Cambridge University Press.

Lieber, Michael D., and Kalio H. Dikepa (1974) Kapingamarangi lexicon. PALI Language Texts: Polynesia. Honolulu: University of Hawai'i Press.

Marck, Jeff (2000) Topics in Polynesian language and culture history. Canberra: Pacific Linguistics.

Milner, George B. (1958) Aspiration in two Polynesian languages. Bulletin of the School of Oriental and African Studies 21: 368-375.

Moyle, Richard M. (2011). Takuu grammar and dictionary: A Polynesian language of the South Pacific. Canberra: Pacific Linguistics, Australian National University.

Moyle, Richard M. (2007) Songs from the second float: A musical ethnography of Takuu atoll, Papua New Guinea. Honolulu: University of Hawai'i Press.

Moyle, Richard M. (1995) Music of Takuu (Mortlock Is.), Papua New Guinea. Occasional Papers in Pacific Ethnomusicology, No. 5. Auckland: University of Auckland.

Næss, Åshild, and Even Hovdhaugen (2011) A grammar of Vaeakau-Taumako. Mouton Grammar Library 52. Berlin: De Gruyter Mouton.

Parkinson, Richard (1907) Dreißig Jahre in der Südsee. Land und Leute, Sitten und Gebräuche im Bismarckarchipel und auf den deutschen Salomoinseln. Stuttgart: Strecker \& Schröder.

Parkinson, Richard (1897) Zur Ethnographie de Ongtong Java- und Tasman-Inseln, mit einigen Bemerkungen über die Marqueen- und Abgarris-Inseln. Internationales Archiv für Ethnographie 10: 104-118, 137-151.

Ray, Sidney H. (1916) Polynesian linguistics. Polynesian languages of the Solomon Islands III. Journal of the Polynesian Society 25 (99): 99-103.

Safert, Ernest, und Hans Damm (1931) Luagiua und Nukumanu, mit Anhang über Sikayana, Nuguria, Tauu und Carteret-Inseln. Halbband 2: Soziale Verhältnisse und Geisteskultur. Hamburg: Friedrichsen, De Gruyter.

Salmond, Anne (1974) A generative syntax of Luangiua: A Polynesian language. The Hague: Mouton.

Scaglion, Richard (2012) Socio-political organization. In: Feinberg, Richard, and Richard Scaglion (eds.), Polynesian Outliers: The State of the Art. Ethnology Monographs No. 21. Pittsburgh: University of Pittsburgh, Pp. $157-171$.

Thilenius, Georg (1902) Etnographische Ergebnisse aus Melanesien. Halle, Ehrhardt Karras. 
А. И. Давлетшин. Кажущийся синхронный звуковой переход в языке таку Папуа - Новой Гвинеи: его значение для сравнительного полинезийского языкознания и теории звуковых переходов.

Во внешнеполинезийском языке Папуа - Новой Гвинеи таку наблюдается синхронный звуковой переход, а именно, замена бокового на дрожащий, однако некоторые говорящие не допускают свободного варьирования $r$ и $l$ в отдельных словах. Показано, что данный переход представляет собой серию из семи звуковых переходов со строго определёнными фонетическими контекстами, причём каждый из них, по всей видимости, инициирует последующий. Поскольку нетривиальные закономерности в варьировании плавных и фрикативных обнаруживаются практически во всех внешнеполинезийских языках синхронно, высказано предположение, что подобного рода переходы много раз случались в истории полинезийских языков и, возможно, ответственны за появления кажущихся нерегулярных фонетических соответствий. Интересно, что находящиеся в контакте с таку близкородственные нукерия и нукуману заимствовали некоторые из правил перехода $r$ в $l$. Работа основана на результатах экспедиции автора 2013 г.

Ключевые слова: синхронный звуковой переход, нерегулярные звуковые переходы, общие фонологические инновации, теория звуковых переходов, геминированные согласные и источники их происхождения, плавные, полинезийские и внешнеполинезийские языки, язык таку. 
